\title{
QUESTÁO PROBATÓRIA NAS DEMANDAS ENVOLVENDO ASSÉDIO MORAL NA RELAÇÃO DE EMPREGO DOMÉSTICO
}

\author{
DOMESTIC EMPLOYMENT'S MORAL HARASSMENT AND PROBATORY ISSUES
}

Ana Paula Villas Boas

Mestranda em Direito Constitucional pelo Instituto Brasiliense de Direito Público - IDP

Defensora Pública Federal

anapaulavb@gmail.com

\section{RESUMO}

O presente trabalho tem como objetivo geral analisar a questáo probatória nas demandas envolvendo assédio moral na relação de emprego doméstico. Para se alcançar a finalidade supramencionada, utiliza-se a metodologia de revisão bibliográfica e jurisprudencial, ou seja, uma pesquisa exploratória com o escopo de buscar esclarecer e ampliar os conhecimentos sobre a problemática a ser desenvolvida. A vulnerabilidade dos trabalhadores domésticos tem raízes históricas sociológicas, delatando uma sociedade de mentalidade escravocrata, que naturaliza a superexploração e a violação de direitos humanos em relação àquele nicho de trabalhadores. Tal realidade resvalou no Direito, no sentido negativo de alijar os domésticos da proteçáo jurídica, negando-lhes direitos mais do que reconhecendo. As conquistas mais expressivas, relacionadas ao trabalho doméstico, foram implementadas somente nos últimos cinco anos, sendo possível afirmar que temos uma quase equiparação daquela categoria com as demais categorias de trabalhadores. No entanto, ainda há muitas disparidades, e no campo processual se vê a nota da vulnerabilidade dos domésticos nos seus parcos instrumentos para provar a violação de direitos, como é o caso do assédio moral, comprometendo-se o acesso à Justiça.

Palavras-chave: Trabalho doméstico. Assédio Moral. Provas. Vulnerabilidade 


\begin{abstract}
This present work has as general objective to analyze the probatory issue in the demands involving moral harassment in the domestic employment's relationship. In order to achieve the aforementioned purpose, the methodology of bibliographical and jurisprudential review are used. Therefore, it was made an exploratory research with the scope of seeking to clarify and broaden the knowledge about the problematic to be developed. The vulnerability of domestic workers has historical sociological roots, betraying a society of slave-like mentality, which naturalizes the overexploitation and violation of human rights in relation to that niche of workers. This reality has slipped in the law, in the negative sense of eliminating the domestic legal protection, denying them rights more than recognizing. The most expressive achievements related to domestic work have been implemented only in the last five years and it is possible to affirm that we are almost equal with the other categories of workers. However, there are still many disparities and in the procedural field one can see the vulnerability of the domestic ones in their meager instruments to prove the violation of rights, as is the case of bullying, compromising access to justice.
\end{abstract}

Keywords: Domestic work. Moral Harassment. Evidences. Vulnerability.

\title{
SUMÁRIO:
}

INTRODUÇÃO 1. ENFRENTAMENTO E LUTA POR ESPAÇOS DE RECONHECIMENTO 2. HISTÓRICO DE (DES)PROTEÇÃO JURỈDICA 3. ASSÉDIO MORAL NA RELAÇÃO DE EMPREGO DOMÉSTICO E QUESTÓES PROBATÓRIAS 4. METODOLOGIA - RESULTADOS DA PESQUISA: ASSÉDIO MORAL POR XINGAMENTOS, GRITOS, HUMILHAÇÃO, E ACUSAÇÃO DE FURTO 5. PRÁTICAS NÁO CONVENCIONAIS NO PROCESSO DO TRABALHO QUE DEVEM SER PROMOVIDAS COMO GARANTIA DE ACESSO À JUSTIÇA. CONSIDERAÇÕES FINAIS.

\section{INTRODUÇÁO}

O trabalho doméstico constitui labor fortemente marcado pelos ranços da escravidão. Quiçá estejamos diante da categoria de trabalhadores - geralmente trabalhadoras, dada a expressividade do gênero feminino entre os domésticos - que mais simboliza a superexploração do trabalho no mundo moderno, sobretudo pela natureza exaustiva do trabalho e pelas jornadas excessivas a que são submetidas.

A categoria, que sempre sofreu desvalorização social, mobilizou-se historicamente pela 
conquista da equiparação dos direitos trabalhistas com os trabalhadores urbanos, luta esta que gerou frutos tardios. Os dois grandes marcos normativos que alçaram os trabalhadores domésticos ao que há de mais próximo da equiparação com os demais trabalhadores foram a Emenda Constitucional no 73/2013 e a Lei Complementar no 150/2015. Antes disso, foram longos anos relegados à invisibilidade, inclusive com seus direitos expressamente excluídos pela Consolidação das Leis Trabalhistas, desde 1943.

É de se notar que, apesar das recentes conquistas, a sociedade ainda não se conscientizou plenamente desse patamar de dignidade conquistado no plano legal pelos trabalhadores domésticos, de modo que ainda se reproduzem padróes de comportamento abusivos e de negação de direitos.

Nesse contexto, é interessante refletir, do ponto de vista sociológico, que, ao se narrar o fenômeno social do ponto de vista do "dominador", a realidade não é retratada integralmente. Isso porque, ao se dar voz ao subalterno, o que se verifica é uma série de distorções, como é o caso do discurso do dominador segundo o qual "a empregada doméstica é tratada como membro da família”. Tal discurso é desmentido contundentemente quando se permite o protagonismo de um discurso contra-hegemônico. É dizer: as empregadas não se sentem como tal.

Deveras, o serviço doméstico desvela uma ambiguidade afetiva ${ }^{1}$, em que há uma intimidade com a família, no cuidado dos filhos e troca de carinhos com as crianças e de informaçóes privadas sobretudo com as patroas, gerando até certa cumplicidade entre as figuras do empregador e do trabalhador. No entanto, ao mesmo tempo subsiste uma forte carga de hierarquia, demarcados os papéis de chefe e de subalterno, sendo inequívoca a existência dessa relação hierárquica.

Tal relação se desdobra em múltiplas formas de subordinação, relacionadas à classe, à raça e ao gênero. E foi justamente essa interseccionalidade que propiciou o processo de fortalecimento político das trabalhadoras domésticas no Brasil, pois o empoderamento da categoria tem intensa relação com os movimentos classistas, negros e feministas, não podendo se omitir, além desses, o papel da Igreja Católica no dito processo. ${ }^{2}$

A discriminação de raça e gênero ínsita às relaçóes de emprego doméstico gerou preocupaçáo no âmbito internacional em relaçáo ao trato isonômico bem como à garantia de um trabalho decente aos domésticos, firmando-se a Convenção da OIT sobre trabalho decente para empregadas domésticas, que decorreu de muitas discussóes por parte dos delegados tripartites, pressupondo-se que:

O trabalho doméstico é uma das atividades para as quais a noção de trabalho decente tem especial importância e, considerando as discriminaçóes de gênero e raça envolvidas, tem estreita relação com a questấo mais ampla da igualdade de oportunidades e tratamento no

1 BRITES, Jurema. Afeto e desigualdade: gênero, geração e classe entre empregadas domésticas e seus empregadores, p. 94.

2 BERNARDINO-COSTA, Joaze. Saberes Subalternos e Decolonialidade: os sindicatos das trabalhadoras domésticas no Brasil. Brasília: Editora Universidade de Brasília, p. 120. 
mundo do trabalho ${ }^{3}$,

No bojo do documento internacional, esclarece-se a noção de "trabalho decente" no seguinte sentido:

Conceito formalizado pela OIT, em 1999, que sintetiza a sua missão histórica de promover oportunidades para que homens e mulheres possam ter um trabalho produtivo e de qualidade, em condiçóes de liberdade, equidade, segurança e dignidade humanas, sendo considerado condição fundamental para a superação da pobreza, a redução das desigualdades sociais, a garantia da governabilidade democrática e o desenvolvimento sustentável ${ }^{4}$.

Em razão de graves violações de direitos humanos deflagradas em face da categoria ora estudada, pode-se dizer que estamos muito distantes do ideal do conceito acima descrito de trabalho decente, havendo ainda um longo percurso, a despeito dos avanços legislativos reportados, para a introjeção de uma nova cultura de respeito ao trabalho doméstico no país.

No âmbito do emprego doméstico se verifica o fenômeno a segregação ocupacional de gênero de forma acentuada: segundo a Organização Internacional do Trabalho, em 2016, o Brasil tinha 6,158 milhóes de trabalhadores domésticos, dos quais $92 \%$ eram mulheres - Desses $92 \%$, apenas $32 \%$ possuem carteira de trabalho assinada ${ }^{5}$. Ou seja, dois terços das domésticas estão compondo a cifra da informalidade.

Isso acontece sobretudo pela divisão sexual do trabalho envolvendo o trabalho reprodutivo. Deveras, a divisão sexual do trabalho no âmbito doméstico tem total pertinência com a classificação do tempo do trabalho em "trabalho pago" (mercado) e "trabalho não pago" (doméstico), sendo certo que os trabalhos femininos, pago e não pago, revelam uma marcante desigualdade de gênero no uso do tempo para o trabalho no Brasil. Está claro que as mulheres invariavelmente trabalham mais do que homens, e muito embora a contribuição dos homens tenha aumentado ao longo dos anos, as mulheres fazem pelo menos duas vezes mais trabalho doméstico que os homens. ${ }^{6}$

Culturalmente, há uma divisão naturalizada entre o trabalho reprodutivo e o produtivo, atribuindo-se o primeiro às mulheres como uma atividade inerente ao gênero. $\mathrm{O}$ trabalho de reprodução social, que é dedicado a atividades para manutençáo da sobrevivência humana, é considerado "não trabalho", sendo marginalizado, ao passo que o trabalho produtivo é, em contrapartida, valorizado e exercido também pelas mulheres, sobre as quais recai, em expressiva maioria, a conhecida dupla jornada.

No âmbito do Judiciário, observa-se esse fato social (da dupla jornada exercida pelas mulheres) sendo reconhecido para se aferir a constitucionalidade de dispositivos que de

3 http://www.ilo.org/brasilia/temas/trabalho-domestico/WCMS_169517/lang--pt/index.htm. Acesso em: 18 jan. 2018.

4 Idem

5 http://www.ilo.org/brasilia/temas/trabalho-domestico/lang--pt/index.htm. Acesso em: 17 jan. 2018.

6 PINHEIRO, Luana Simóes, MEDEIROS, Marcelo. Desigualdades de gênero em tempo de trabalho pago e náo pago no Brasil. Rio de Janeiro: Ipea, 2013. 
certa forma favorecem as mulheres. É o caso do art. 384 da CLT (que impóe intervalo de 15 minutos antes de se começar a prestaçáo de horas extras pela trabalhadora mulher), dispositivo, contudo, que foi revogado pela Lei 13.467/17. De toda sorte, a decisão foi emblemática por destacar a diferenciação fisiológica e psicológica entre homens e mulheres, salientando o maior desgaste natural da mulher trabalhadora, sem se olvidar da dupla jornada de trabalho a que as mulheres se submetem, as quais suportam maior peso na administração da casa e da educaçáo dos filhos. ${ }^{7} \mathrm{E}$ o mesmo fundamento lastreia a constitucionalidade da diferenciação dos critérios para aposentadoria da mulher.

O recorte de gênero, ora apontado, é uma das facetas da vulnerabilidade da trabalhadora doméstica no contexto brasileiro, mas não podemos nos olvidar da transversalidade $\mathrm{da}$ questão racial, da questão social e da mais perversa violação de direitos humanos que é o trabalho doméstico infantil.

Segundo a Convenção da OIT sobre as piores formas de trabalho infantil (Convenção $n^{\circ} 182$ ), ratificada pelo Brasil em 02/02/2000, prevê entre eles o trabalho doméstico. No Brasil, segundo o Pnad (IBGE) de 2015, ainda há 2,7 milhóes de crianças e adolescentes em situação de trabalho infantil no país. Também é alarmante que o trabalho infantil entre crianças de cinco a nove anos aumentou 12,3\% entre 2014 e 2015, passando de 70 mil para $79 \mathrm{mil}^{8}$. A maioria dessas crianças são meninas, e muitas delas realizam trabalho doméstico em consequência de serem vítimas de trabalho forçado ou de tráfico de pessoas. Ou seja, cuida-se de realidade sobremaneira preocupante e assoladora.

\section{ENFRENTAMENTO E LUTA POR ESPAÇOS DE RECONHECIMENTO}

Sobre o enfrentamento das violaçóes de direito envolvendo trabalho doméstico, atribui-se ao processo de fortalecimento político das domésticas no Brasil as conquistas legislativas, muito embora tardias, em reconhecimento à dignidade desse importante ramo do trabalho. Isso porque representou uma ruptura do silenciamento e a emersão de um discurso contra hegemônico que conquistou, pouco a pouco, um espaço também no mundo jurídico.

Foi árduo o processo de construção de associaçóes e sindicatos daquela categoria profissional, valendo destacar a importância da interseccionalidade nessa articulaçâo política com outros atores sociais, especialmente movimentos classistas, feministas e negros, o que propiciou o fortalecimento político e o empoderamento das trabalhadoras domésticas no país?:

(...) é evidente que se estabeleceu uma relação de mão dupla entre o movimento das trabalhadoras domésticas e os movimentos negro, fe-

7 TST. RECURSO DE REVISTA: RR-1540/2005-046-12-00.5, 7a Turma, Relator: Min. Guilherme Augusto Caputo Bastos, DJ: 04/05/2009.

8 http://www.ilo.org/brasilia/temas/trabalho-infantil/lang--pt/index.htm. Acesso em: 18 jan. 2018.

9 BERNARDINO-COSTA, Joaze. Saberes Subalternos e Decolonialidade: os sindicatos das trabalhadoras domésticas no Brasil. Brasília: Editora Universidade de Brasília, 2015, p. 73. 
minista e sindical, no sentido de que tanto o Sindoméstico leva as suas reivindicaçóes específicas para o interior desses movimentos quando traz as contribuiçóes desse movimento para a própria categoria ${ }^{10}$.

Foram expressivas as manifestações públicas das empregadas domésticas engajadas na luta por um patamar de direitos mínimo, seja nos Encontros e Congressos Nacionais das Trabalhadoras Domésticas, passeatas, mobilizaçóes em frente às Assembleias Legislativas dos Estados, boletins do sindicato, além de participação em fóruns feministas, de movimento negro. Entre as reivindicaçóes da categoria, se destacam a jornada de trabalho de 40 horas semanais, o direito ao $13^{\circ}$ salário, ao descanso semanal remunerado, ao FGTS obrigatório e ao seguro-desemprego.

Além da pauta trabalhista, também se engajaram na luta por direitos outros, como o de morar na própria casa, o que era visto até como uma pré-condição para a formação da consciência de classe ${ }^{11}$, rompendo-se os laços com a patroa e construindo um espaço de liberdade. Some-se a isso o combate à discriminação no uso do elevador social, o que gerou muita polêmica e manifestaçóes dos trabalhadores domésticos, e todas as discussóes sobre o resgate da autoestima da categoria, que sempre sofreu com a vergonha e o estigma de mencionar sua profissão. Enfim, registrem-se as atuaçóes no combate à discriminação racial e ao assédio sexual.

A colaboração da Igreja Católica no fortalecimento da articulação nacional das trabalhadoras domésticas, por meio dos grupos da Pastoral da Doméstica, focada na questão de classe e na valorização da pessoa humana foi essencial. ${ }^{12}$ Também é de se registrar o relacionamento com movimentos classistas, especialmente a CUT.

Aos poucos a categoria foi construindo um movimento nacional, congregando sindicatos e associações. Como importante marco cita-se a criação da FENATRAD - Federação Nacional das Trabalhadoras Domésticas - em 1997, responsável por qualificar a articulação e dar maior visibilidade às trabalhadoras. A aprovação da EC no 72/2013 e da Convenção e Recomendação sobre trabalho decente para as trabalhadoras domésticas da OIT em 2011 são resultado direto da atuação da Fenatrad. ${ }^{13}$

\section{HISTÓRICO DE (DES)PROTEÇÁO JURÍDICA}

É inquestionável a importância do trabalho doméstico remunerado como uma atividade essencial para o bom funcionamento da economia, por viabilizar a reproduçáo social e da força de trabalho. No entanto, apesar de sua relevância central para a organização social e econômica do país, o trabalho doméstico ainda se caracteriza pela invisibilidade, desvalorização, informalidade, baixos salários e violaçóes aos direitos da categoria.

\footnotetext{
$10 \quad$ Ibidem, p. 152.

11 Idem, p. 106.

12 Idem, p. 120.

13 Idem, p. 207.
} 
Na seara do Direito, o que se verifica historicamente é uma expressa segregação daquele nicho de trabalhadores, podendo-se falar, mais propriamente, de um histórico de desproteção jurídica. A começar pela CLT, de 1943, que na sua redação dada pelo Decreto-lei no 8.079, 11.10.1945 excluiu o trabalho doméstico do seu campo de aplicação:

Art. $7^{\circ}$ Os preceitos constantes da presente Consolidação salvo quando for em cada caso, expressamente determinado em contrário, não se aplicam:

a) aos empregados domésticos, assim considerados, de um modo geral, os que prestam serviços de natureza não-econômica à pessoa ou à família, no âmbito residencial destas.

Maurício Godinho Delgado e Gabriela Neves Delgado, ao tratar do ciclo de institucionalização da cidadania trabalhista doméstica, elaboraram uma interessante categorização baseada em níveis de cidadania proporcionados pela ordem jurídica na tutela dos interesses da categoria profissional estudada. Cuida-se de três ciclos: ${ }^{14}$

Cidadania deflagrada. O parâmetro normativo é a Constituição de 1988. Antes disso o que se observava era uma exclusão civilizatória ${ }^{15}$ acentuada, em que a proteção jurídica era muito tímida. A Lei 5.859/72 limitava-se a garantir, como direitos trabalhistas, a assinatura da Carteira de Trabalho e a concessão de férias anuais remuneradas de 20 dias úteis. A categoria tinha uma cidadania mínima, sendo que o ciclo de institucionalização da cidadania trabalhista doméstica se inaugurou com a Carta de 1988, prevendo um rol de doze direitos aos trabalhadores domésticos, apesar de ainda persistirem muitas omissóes.

Cidadania ampliada. Com a Lei $n^{\circ} 11.324 / 06$, ampliou-se a garantia de direitos aos domésticos, acrescentando-se o descanso semanal em feriados, 30 dias de férias, garantia de emprego à gestante, proibiçáo de desconto no salário do empregado por fornecimento de alimentação, vestuário, higiene ou moradia, além de criar incentivo fiscal ao empregador doméstico. Some-se a esse diploma a aprovação da lista TIP em 2008 (Lista das Piores Formas de Trabalho Infantil), em que incluiu o serviço doméstico, e a Lei no 12.506/2011 que finalmente regulamentou o aviso prévio proporcional.

Cidadania consolidada. Por fim, a Emenda Constitucional $\mathrm{n}^{\mathrm{o}}$ 72/2013 e a Lei Complementar no 150/2015, sendo que a primeira estendeu 16 novos direitos aos empregados domésticos, remetendo, porém, alguns deles à regulamentação legal, o que foi implementado em 2 de junho de 2015 com a LC 150. Uma das conquistas mais marcantes da categoria doméstica proporcionada pela EC foi a jornada de trabalho. Com a Lei Complementar referida, completou-se a plenitude do ciclo de institucionalizaçẫo da cidadania trabalhista para

\footnotetext{
14 O novo manual do trabalho doméstico - com os comentários aos artigos da LC n. 150/2015. 2a ed., São Paulo: LTR, 2016.

15 Idem, p. 17.
} 
Note-se que somente em 1988, com a Constituição Cidadá, é que reconheceu o direito à sindicalização dos trabalhadores domésticos. Em razão disso, muitas associações que existiam foram transformadas em Sindicato dos Trabalhadores Domésticos, como aconteceu no Rio de Janeiro, por exemplo. Isso explica o maior empoderamento da categoria, o que contribuiu sobremaneira para a conquista dos direitos supervenientes.

Esse histórico relacionado à tutela de direitos, portanto, é majoritariamente marcado pela desproteção, de modo que o trabalho doméstico por muitos anos esteve distante do conceito de trabalho decente no Brasil. A proteção veio assumir proporçôes consideráveis somente com a Emenda Constitucional no 73/2015, bem como a Lei Complementar $n^{\circ}$ $150 / 2015$, que representaram uma relevante conquista, sendo pertinente destacar, porém, que a eficácia dessas normas ainda está em construção.

De acordo com pesquisa feita com dados da Pesquisa Nacional por Amostra de Domicílios (Pnad), do Instituto Brasileiro de Geografia e Estatística) nos anos de 2011 a 2014, sobre os efeitos da EC 72/2013 para o grupo das empregadas domésticas (mensalistas), maiores de 18 anos de idade e em áreas urbanas ${ }^{16}$, observou-se:

a) O aumento da probabilidade de mensalistas terem a CTPS assinada (ou seja, o aumento da formalidade).

Gráfico 1: probabilidade de mensalistas terem a CTPS assinada

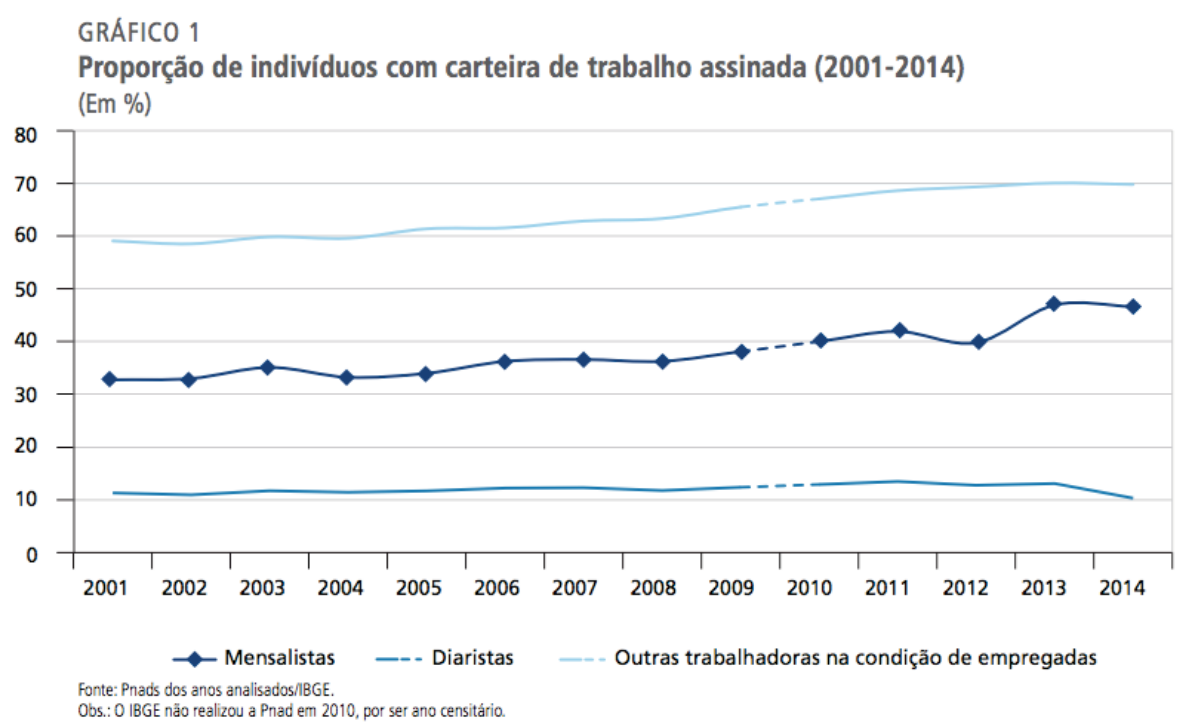

16 COSTA, Joana Simões de Melo, BARBOSA, Ana Luiza Neves de Holanda e HIRATA, Guilherme. Efeitos da Ampliaçáo dos Direitos Trabalhistas sobre as condiçóes de trabalho das empregadas domésticas. Rio de Janeiro: Ipea, 2016. 
b) A redução da jornada de trabalho.

Gráfico 2: Reduçáo da jornada de trabalho

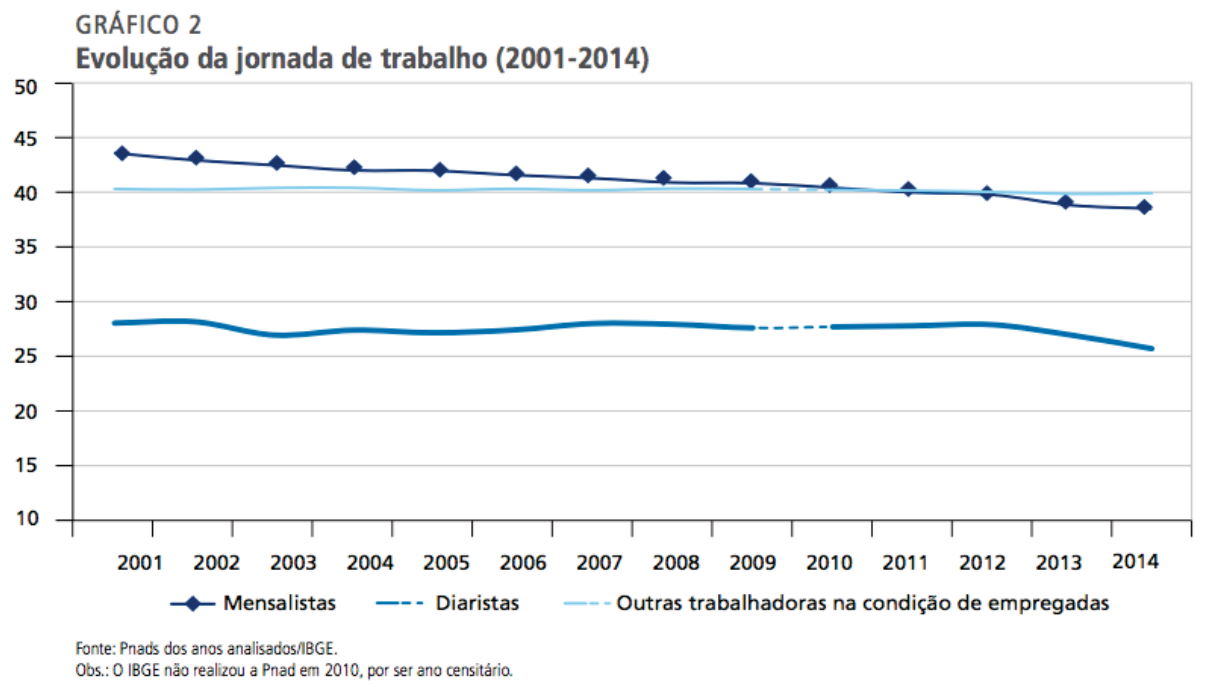

Ou seja, houve um aumento e $7 \%$ na taxa de formalização de mensalistas (nos seis meses após a EC 72, mantendo-se estável nos 12 meses seguintes). Muito embora não se saiba se o acréscimo decorreu da transição da informalidade para a formalidade das mensalistas ou se foi uma mudança na composiçấo do grupo de mensalistas (inserindo-se diaristas).

Também se observou, após a alteração legislativa, a reduçáo de 0,5 hora a jornada das empregadas domésticas mensalistas, o que não surtiu efeito entre as diaristas. De todo modo, é certo que tal impacto ainda é inexpressivo, ainda mais diante da jornada excessiva usualmente desempenhada trabalhadoras domésticas, o que é fato notório.

\section{ASSÉDIO MORAL NA RELAÇÃO DE EMPREGO DOMÉSTICO E QUES- TÓES PROBATÓRIAS}

Nos atendimentos prestados a trabalhadores domésticos na experiência prática da pesquisadora ${ }^{17}$, verifica-se que muitos relatos referentes a abusos de ordem moral praticados pelo empregador (ou empregadores) têm sido represados, não sendo pleiteada a reparação civil desde o início ou, quando o caso é submetido ao Judiciário, o resultado mais provável é que seja julgado improcedente por não ter lastro probatório ou por insuficiência das provas.

\footnotetext{
17 Aqui tem-se como referência prática as demandas apresentadas perante a Defensoria Pública da União, considerando que a autora deste trabalho atua como Defensora Pública Federal em Brasília/DF, na especialidade trabalhista, desde 2012 até a publicação deste artigo.
} 
Os relatos dizem respeito, sobretudo, a xingamentos, humilhações, injúrias raciais, acusaçôes de furto e a imposição de uma jornada exaustiva, todas essas condutas caracterizadoras de dano de natureza extrapatrimonial. Quando algum ou alguns membros da família menosprezam a trabalhadora, a desqualificam, insinuam que está furtando, por exemplo, e o fazem sistematicamente, praticam assédio moral. Ademais, quando a sujeitam a uma jornada exaustiva, pode-se entender que precisamente incorrem dano existencial.

Alusões frequentes de assédio moral dizem respeito à gravidez da empregada, o que é encarado com insensibilidade e mesmo negatividade pelos empregadores, temendo as possíveis faltas e o déficit de desempenho da gestante. Muitas vezes, aqueles praticam o assédio moral com intuito de forçar a empregada a pedir demissão para não ter que arcar com os ônus da estabilidade da gestante, raramente preocupados com a vulnerabilidade da empregada e do nascituro.

O assédio moral é rotineiro nas relaçôes de emprego doméstico, e é mais grave nesses casos porque é ocultado pelos intramuros da relação, tornando o trabalhador invisibilizado e, assim, mais desprotegido pelos mecanismos de coibição da violência pelo Estado. Ademais, reproduz uma dominação histórica, em que se legitimava toda sorte de violência em face do trabalhador doméstico, reificado pela escravidão, o que ainda produz seus efeitos no ranço escravocrata presente na mentalidade dos empregadores do século XXI.

Para se configurar o assédio moral na relação de emprego doméstico, é necessário que a conduta abusiva do empregador (e, aqui, vale destacar que o empregador doméstico é qualquer membro familiar para quem o doméstico preste serviços) se dê de forma sistemática, reiterada, e não pontualmente. A violação aos direitos da personalidade do trabalhador pode ocorrer de diversas formas, sempre afrontando a dignidade deste. Entre as consequências dessa violência, pode-se citar o estresse, ansiedade, depressão e distúrbios psicossomáticos.

A pensadora francesa Marie-France Hirygoyen, propóe uma precisa definição da violência aqui estudada, que merece transcrição:

o assédio moral no trabalho é definido como qualquer conduta abusiva (gesto, palavra, comportamento, atitude...) que atente, por sua repetição ou sistematização, contra a dignidade ou integridade psíquica ou física de uma pessoa, ameaçando seu emprego ou degradando o clima de trabalho ${ }^{18}$.

Pontue-se que as agressóes que acontecem uma vez ou esporadicamente podem caracterizar danos morais, também passíveis de reparação civil. O recorte metodológico do presente estudo, porém, diz respeito tão-somente ao assédio moral, não abrangendo o tema genérico do "dano moral", que é bem mais amplo. O que se visa, portanto, são os danos morais por assédio moral reconhecidos pelo Judiciário.

Os pedidos de danos morais, na Justiça do Trabalho, geralmente estáo associados ao descumprimento de deveres legais (tais como falta de anotação da CTPS, a retenção indevi-

18 HIRIGOYEN, Marie-France. Assédio Moral: a violência perversa do cotidiano, p. 17. 
da da carteira profissional, a ausência de contribuição previdenciária ao longo do pacto laboral, a título de exemplo). Também é comum o pedido de indenizaçáo por danos extrapatrimoniais em caso de doença do trabalho, o que não é o foco.

Quanto à menção de assédio moral relacionado à exigência de trabalho excessivo, entendese que a conduta não se enquadra exatamente no conceito de dano moral estrito senso ou de assédio moral, mas sim de dano existencial, que é uma das modalidades de dano extrapatrimonial. É uma conduta perversa e bastante preocupante na seara do trabalho doméstico, por privar o trabalhador dos seus projetos de vida, das formas de manifestaçáo da sua liberdade e personalidade no mundo, podendo, inclusive, caracterizar tipo penal de trabalho em condição análoga à de escravo. Entretanto, não compóe a temática deste estudo.

Feitas essas consideraçôes, abordaremos doravante as formas como o assédio moral se manifesta no mundo do trabalho doméstico, e por fim investigaremos a delicada questáo probatória quando a demanda é levada aos tribunais.

\section{METODOLOGIA - RESULTADOS DA PESQUISA: ASSÉDIO MORAL POR XINGAMENTOS, GRITOS, HUMILHAÇÃO, E ACUSAÇÃO DE FURTO}

Com o objetivo de mapear as açóes judiciais trabalhistas que visam o reconhecimento do assédio moral e consequente pedido de reparação de danos de natureza extrapatrimonial nas relações de emprego envolvendo trabalhadores e trabalhadoras domésticas, a pesquisadora analisou ações judiciais, a partir do banco de dados do site "Jusbrasil", 19 adotando como critério de pesquisa as expressóes "empregada doméstica" ${ }^{20}$ e "assédio moral”.

Elegemos como filtro "todos os TRTs", e a delimitação cronológica "último ano", abrangendo, portanto, todos os processos de 2017, de modo que obtivemos 106 resultados ${ }^{21}$. Por parecer factível e suficiente a análise desses 106 julgados, assim o fizemos, para, em um segundo momento, analisar casos envolvendo empregados náo domésticos.

Assim, a pesquisa deteve-se aos julgados selecionados pelo renomado sítio de pesquisa de jurisprudência no ano de 2017, excluindo-se aqueles em que os termos de pesquisa aparecem em contextos diversos, não atinentes ao tema estudado, ou repetidamente. Por exemplo, foram excluídas demandas contra pessoa jurídica (salvo desvio de função).

Dessa depuração, restaram 44 hipóteses pertinentes ao objeto de pesquisa, julgados estes que foram analisados detidamente. Fez-se um cotejo com outros 44 resultados

19 Disponível em: www.jusbrasil.com.br.

20 Vale esclarecer que a variação de gênero ("empregado doméstico") não produziu alteração no número de resultados.

21 Disponível em: www.jusbrasil.com.br/jurisprudencia/busca?q=dom\%C3\%A9stica+dano+moral+provas\&idtopico=T10000009\&l=365dias. Acesso em: 23 dez. 2017. 
aleatórios, também no último ano, julgado por TRTs, envolvendo assédio moral em relação a trabalho não doméstico, para ter um comparativo e se traçar as conclusóes que aqui logramos desenvolver.

Quanto aos resultados da pesquisa, convém esclarecer os seguintes pontos: a) quando se indica "provimento" do recurso, diz-se especificamente do capítulo de sentença que reconheceu o assédio moral em face da empregada doméstica; b) quando o recurso é do reclamado, mas o acórdão confirma a sentença, indica-se no campo "decisão" "sentença favorável" confirmada pelo Tribunal, também relativamente ao capítulo de sentença em questấo.

Quanto aos gráficos representativos das estatísticas, ao se mencionar os resultados como "procedente" e "improcedente":

a) "Procedente" inclui-se: as sentenças que reconheceram o pedido de danos morais por assédio moral que não foram reformadas, nesse capítulo específico, pelo Tribunal Regional, bem como os acórdãos que acolheram os danos morais por assédio moral, diferentemente do que foi reconhecido pelo órgáo a quo;

b) "Improcedente" inclui-se, paralelamente, os acórdãos que não deram provimento aos recursos contra as sentenças improcedentes quanto ao pedido de danos morais por assédio moral, e os acórdãos que deram provimento ao recurso do reclamado que se insurgiu contra o reconhecimento de danos morais por assédio moral pelo juiz singular.

Pontue-se que não se trata de uma mera simplificação, mas racionalizaçâo das conclusôes, afinal todos os elementos contidos em cada conteúdo têm significado equivalente.

Verificou-se, pois, que o assédio moral, na maioria dos casos que chegam ao Judiciário, dizem respeito a ofensas verbais, como xingamentos, gritos, humilhaçôes, tratamento ríspido ou grosseiro, sendo também bastante frequente as acusaçôes ou insinuaçôes de furto. Não raro, a injúria tem conotação racial e faz alusão ao trabalho de escravo, como é o exemplo de a empregada ser chamada de "mucama".

Como já mencionado, o nicho de trabalhadores objeto do nosso estudo está inserido em um contexto de maior vulnerabilidade, por várias razões, entre elas a própria invisibilidade das relaçóes desenvolvidas no recôndito do lar. $\mathrm{O}$ assédio sofrido nos redutos da casa em que presta serviços é mais grave por não haver testemunhos, deixando a vítima ainda mais desprotegida. É oportuno citar:

Quando a vítima do dano derivado da violaçáo de um direito fundamental é o empregado, a situação mostra-se mais grave pela vulnerabilidade própria da subordinaçáo jurídica e da hipossuficiência econômica, que acabam minando qualquer possibilidade de exercício do direito de resistência, tornando mais dolorosos os efeitos das agressóes perpetradas. ${ }^{22}$

Quando se trata de assédio moral ao trabalhador, diz-se da violação de direitos fundamen-

22 JÚNIOR, Antonio Umberto de Souza. O novo direito do trabalho doméstico de acordo com a Lei Complementar n. 150/2015. São Paulo: Saraiva, 2015, p. 83-84. 
tais, previstos na Constituição, e de direitos da personalidade, coincidentes ou não com aqueles, previstos no Código Civil, gerando a incidência de normas de responsabilidade civil (art. 186 e art. 927 do Código Civil) que fundamentam a reparação de danos morais. $\mathrm{O}$ assédio moral também caracteriza justa causa do empregador, a amparar a rescisão indireta do contrato de trabalho.

Na pesquisa realizada, em mais de $70 \%$ dos casos o assédio moral consistia em injúria, às vezes somada a outras formas de suposto assédio, como acusaçóes de furto. Diz-se "injúria” para abranger agressóes verbais, humilhaçôes, gritos, e tratamento desrespeitoso em geral. Foram inexpressivos os julgados em que a trabalhadora alegou, como fato ensejador de assédio moral, a jornada excessiva e o excesso de rigor no trato das tarefas diárias, com puniçóes exageradas.

Não há dúvidas que o tratamento desrespeitoso do trabalhador no ambiente de trabalho doméstico, quando sistemático, caracteriza o assédio moral, atingindo os direitos da personalidade do trabalhador, e, portanto, sua dignidade da pessoa. Como consequência do reconhecimento da caracterização do assédio moral, também é incontroverso o direito à indenização. A questão é que esse reconhecimento não costuma acontecer no Judiciário trabalhista por uma razão técnica referente ao ônus da prova. É o tema sobre o qual nos debruçaremos.

Cabe ao empregado que alega ocorrência de assédio moral, via de regra, demonstrar o ocorrido, em razão da distribuição do onus probandi pela legislação pátria (art. 818 da CLT e art. 333, I, do CPC). Acontece que no âmbito doméstico, geralmente não há testemunhas dos fatos.

Todo o núcleo familiar, para quem são prestados os serviços domésticos, compõe o polo passivo da demanda relacionada ao vínculo de emprego, ou seja, os membros da família são partes na relação jurídica processual. Eventuais testemunhas poderiam consistir em outros empregados, ou quiçá vizinhos, mas é muito dificultosa a prova oral, e é até intuitiva essa ilaçâo.

Diferentemente, nos vínculos empregatícios em empresas, os próprios colegas podem testemunhas tratamento vexatório por parte de prepostos da pessoa jurídica, ou mesmo confirmar que sáo vítimas da mesma forma de violência verbal ou moral, servindo como eficientes testemunhas.

Quanto à prova documental, tem sido cada vez mais comum a apresentação de conversas de whatsapp ou outro aplicativo de conversas com textos e imagens. Patroas (diz-se assim, pois as mulheres é que mais comumente assumem a gestão das atividades do lar) e empregadas se comunicam com frequência por tais meios, o que pode ensejar prova documental de ofensas, se for o caso. Vale registrar a validade do mencionado meio de prova para fundamentar decisōes judiciais (art. 369 do Código de Processo Civil).

Nas hipóteses analisadas, verificou-se que em $78 \%$ das demandas houve alegação de injúria, ao lado de acusaçôes de furto, jornada exaustiva, dispensa durante a estabilidade da gestante e excesso de rigor. Retratamos os resultados no gráfico abaixo: 


\section{Gráfico 3: Formas de assédio moral}

Mapeado o assédio moral nas relaçóes de trabalho doméstico nas linhas volvidas, mostrase oportuno demonstrar os resultados das demandas levadas ao Judiciário e que foram objeto de recurso referentes ao tema. Senão vejamos:

Gráfico 4: Resultados das demandas de trabalhador doméstico (assédio moral)

\section{Formas de assédio moral}

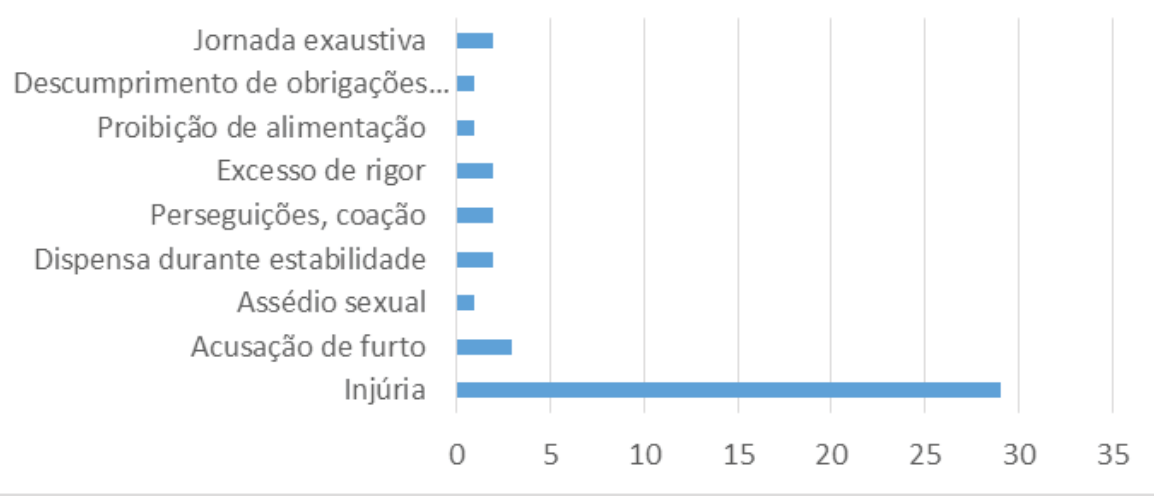

Extrai-se que em somente dois julgados a parte reclamante logrou comprovar o assédio moral mediante prova testemunhal. Nos quatro casos em que houve resultado "procedente", tal decorreu de um imperativo processual em razão da confissão ficta imposta pela revelia do reclamado, ou por se aplicar o dano moral in re ipsa em caso de dispensa de gestante em período de estabilidade.

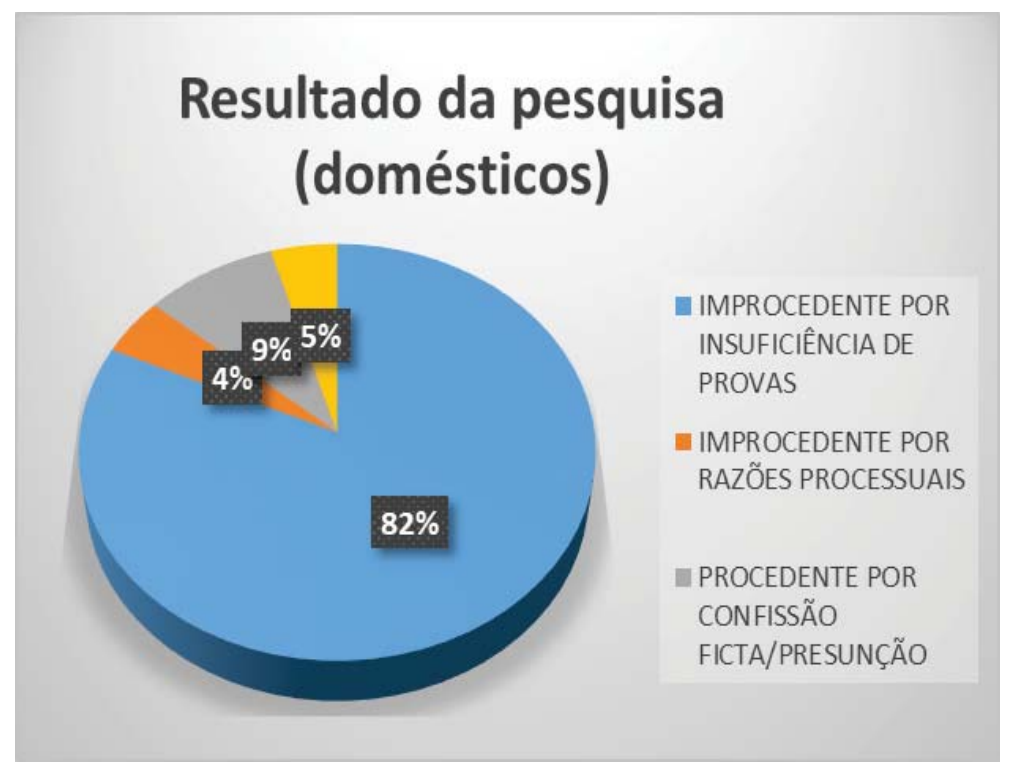


Firmado esse cenário, cotejamos com outros 44 casos aleatórios em que existia alegação de assédio moral, com os mesmos filtros indicados (TRTs, ano de 2017 e com a restrição de não se tratar de relação doméstica), chegando aos seguintes resultados:

Gráfico 5: Resultado das demais demandas

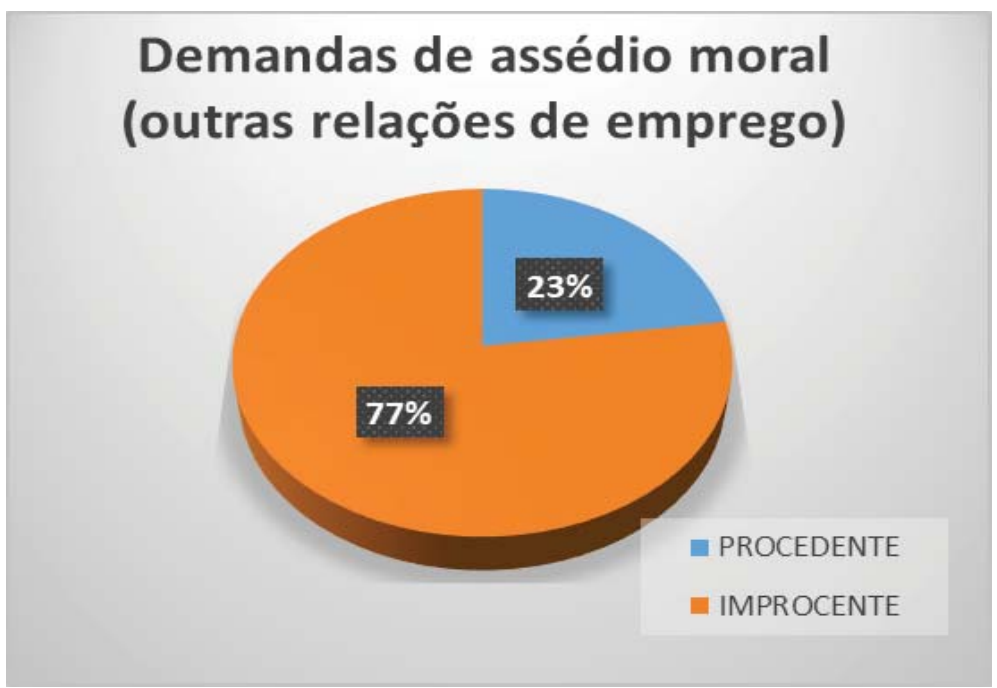

Conclui-se dos resultados da pesquisa que há 4,6 vezes mais chances de um trabalhador náo doméstico comprovar o dano extrapatrimonial decorrente do assédio moral do que $o$ trabalhador doméstico, e que o reconhecimento do pedido com base em presunção legal tem quase o dobro de incidência em relação aos casos em que o reclamante obtém êxito na produção de provas.

Ou seja, cuida-se de uma evidente disparidade, em que o trabalhador doméstico, por circunstâncias inerentes à relação de emprego a que é submetido, em um ambiente privado e com raras possibilidades de testemunho ou ingerência do Estado na entrincheirada morada da família, tem escassos meios de comprovar violaçóes de ordem moral ocorridas no labor.

Com base nessa constataçáo, especularemos sobre como os meios de prova podem auxiliar um juiz sensível a tal desigualdades de armas, a fim de se atenuá-las, promovendo o acesso a uma ordem jurídica justa e efetiva aos trabalhadores domésticos. Acredita-se que a soluçâo, para tanto, deve vir de forma criativa, a pedido ou não do patrono do empregado, devendo contar com o respaldo e sensibilidade do Judiciário Trabalhista.

\section{PRÁTICAS NÁO CONVENCIONAIS NO PROCESSO DO TRABALHO QUE DEVEM SER PROMOVIDAS COMO GARANTIA DE ACESSO À JUSTIÇA}


Entendemos que há alternativas para se se propiciar o acesso a uma ordem jurídica justa e efetiva aos trabalhadores domésticos em posição desvantajosa no tocante à produção de provas. Tais soluçôes são previstas pelo ordenamento jurídico, mas não são usualmente adotadas, havendo resistência pelo Judiciário Trabalhista para tanto. É o que pretendemos desenvolver em sequência, abordando antes um importante princípio que permeia toda a temática, e que é norteador do processo do trabalho, qual seja, o princípio da oralidade.

\section{a) PRINCÍPIO DA ORALIDADE NA JUSTIÇA DO TRABALHO}

O princípio da oralidade valoriza a prova oral no processo juslaboral e prioriza que a causa seja julgada pelo juiz que a colheu. Segundo Mauro Schiavi, o princípio da oralidade de decompóe nos seguintes subprincípios ${ }^{23}$ : a) identidade física do juiz, pelo qual o juiz que instruiu o processo e colheu diretamente a prova é que deve julgá-lo, pois detentor de maiores condiçóes de valorar a prova; b) prevalência da palavra oral sobre a escrita, com prioridade aos atos de audiência; c) concentração dos atos processuais em audiência; d) imediatidade do juiz na colheita da prova, de modo que os atos instrutórios devem se dar perante a pessoa do juiz, formando melhor seu convencimento, inclusive se valendo de impressóes obtidas no momento; e) Irrecorribilidade das decisões interlocutórias, o que proporciona maior celeridade e valoriza a autoridade do juiz na condução do processo.

Carlos Henrique Bezerra Leite aponta como aplicaçáo do referido princípio a previsão de reclamação verbal (art. 840, $\$ 2^{\circ}$ da CLT), a possibilidade de defesa oral do reclamado (art. 847 da CLT), na ocasião da audiência, em que as partes de dirigem direta e oralmente ao magistrado, propiciando debates, e também as açôes trabalhistas de alçada (Lei 5.584/70), com predomínio da palavra falada sobre a escrita. ${ }^{24}$

Naturalmente, o juiz que presidiu os depoimentos pessoais, interrogatórios e oitiva das testemunhas certamente tem mais elementos - aqueles dificilmente registráveis por escrito - para proferir um julgamento mais próximo do ideal de Justiça. Esse contato direto com as partes e testemunhas permite ao juiz aferir as nuances do comportamento que indicam a veracidade e confiabilidade ou não dos elementos probatórios.

Convém transcrever trecho do voto do Desembargador Federal do Trabalho Ricardo Areosa, no Agravo de Instrumento em Recurso Ordinário n: 0001227-04.2011.5.01.0061, $10^{\text {a }}$ Turma, no seguinte sentido:

(...) 2.4. Caracteriza-se o cerceio de defesa quando o juiz profere sentença desfavorável ao autor da ação, indeferindo oitiva de testemunha, através da qual o autor pretendia provar o fato constitutivo de seu direito.

2.5. Mais do que isso, a oitiva das testemunhas é o momento em que

23 Manual de Direito Processual do Trabalho, p. 111-112.

24 Art. $20 \$ 3^{\circ}$. Quando o valor fixado para a causa, na forma deste artigo, não exceder de 2 (duas) vezes o salário-mínimo vigente na sede do Juízo, será dispensável o resumo dos depoimentos, devendo constar da Ata conclusão da Junta quanto à matéria de fato. 
o juiz tem oportunidade de acompanhar as reaçóes das partes diante das perguntas formuladas, verificando se respondem com segurança, se tergiversam ou se contornam com evasivas. Há uma relação imediata, dinâmica e profícua, tudo na busca da verdade. Apenas o Juízo sentenciante tem condiçóes de extrair a verdade dos fatos, pois a fase de instruçáo proporciona uma proximidade física entre magistrado e jurisdicionados, capacitando aquele a detectar indícios de inidoneidade.

Aliás, o culto ao "escrito" pode gerar distorções graves, pois pelo poder da retórica, uma grande inverdade pode ser transformada em uma eloquente tese de defesa. Essa supervalorização do elemento escrito é simbolizada no jargão "o que não está nos autos não está no mundo", retratando uma cultura burocrática e um arquétipo de juiz intocável, impassível, e que não participa ativamente do processo.

Observa-se, contudo, uma visível mudança de mentalidade ao longo dos tempos, de modo que o princípio da oralidade também rege o processo civil comum, muito embora seja mais marcante na Justiça do Trabalho e também na sistemática dos Juizados Especiais. É a prova oral que deve ser exaltada, no objeto do presente estudo, para se promover um processo mais isonômico e efetivo, consoante veremos nos próximos tópicos.

Pondera-se, assim, que ao se deduzir pretensão de reparação de danos morais por parte do empregado doméstico, deve ser dedicado um cuidado ainda maior com provas orais, oportunizando em grau máximo a sua produção, sobretudo com o interrogatório das partes, e analisando cuidadosamente a possibilidade de distribuição dinâmica do ônus da prova, o que será casuístico.

\section{b) DEPOIMENTO PESSOAL E INTERROGATÓRIO. CONFISSÁO}

O depoimento da parte traduz-se em uma importante fonte de prova. Cuida-se do momento em que as partes se colocam em contato imediato com o juiz, colaborando para a formação do seu convencimento, em observância ao princípio da oralidade. Ao tratar de "depoimento pessoal" (art. 385 do CPC) o legislador, na verdade, prevê duas figuras distintas: a do depoimento pessoal e a do chamado interrogatório livre.

Enquanto o primeiro tem específico fim probatório, sendo o objetivo principal obter a confissão da parte adversa, o segundo "é antes uma forma de esclarecimento de que se vale o juiz para melhor inteirar-se dos fatos do processo do que propriamente um meio de prova" 25 . Ademais, o depoimento da parte exige o requerimento da parte contrária (por isso é chamado depoimento por provocação) contrária e tem momento próprio para acontecer no iter processual, e, diversamente, o interrogatório é medida adotada de ofício pelo juiz e pode ser determinada em qualquer fase do processo.

Nos interessa, para fins acadêmicos, o depoimento pessoal para análise da prova de assédio moral. Antes, cumpre rememorar que, na relaçáo de emprego doméstico, devem figurar

25 MARINONI, Luiz Guilherme, ARENHART, Sérgio Cruz. Prova, p. 388. 
no polo passivo todos os integrantes da família, pois por conceito empregador é a pessoa ou os integrantes da família ${ }^{26}$. Segundo Antônio Umberto de Souza Júnior:

(...) em se tratando de uma família empregadora, opera-se circunstância especial em que um único contrato encontrará um feixe de tomadores simultâneos, desde os adultos provedores até a criança da mais tenra idade. ${ }^{27}$

Sendo assim, aqueles para quem o empregado doméstico presta serviços, ou seja, todos os membros da família que usufruem do labor doméstico são considerados empregadores domésticos, e todos podem ser responsabilizados. Portanto, no caso de sentença favorável, esta formará título executivo judicial contra todos os integrantes da família para quem o empregado ou empregada prestou serviços.

Por essa peculiaridade que o empregador doméstico pode ser representado por qualquer dos familiares que componha a família nas audiências perante a Justiça do Trabalho, consoante permissivo sumulado ${ }^{28}$. Note-se que a hipótese se amolda à figura do litisconsórcio passivo unitário, pois se pressupóe a incindibilidade da relação jurídico-material, de modo que a decisão deve ser a mesma em relação a todos os litisconsortes. Tal litisconsórcio é, em tese, obrigatório, muito embora na praxe os juízes e tribunais atribuam eficácia do título executivo a todos os familiares, independentemente de terem ou não figurado no polo passivo.

Quanto ao interrogatório, acredita-se que, no caso de alegação de assédio moral, deva ser utilizado com maior frequência, considerando que a parte não pode pedir o próprio depoimento pessoal, e a hipossuficiência processual acentuada quando o reclamante é trabalhador doméstico, pelas razóes já delineadas. Fazendo o interrogatório de ambas as partes visando esclarecer os fatos, o juiz terá elementos, para além da objetividade dos discursos, municiando-o de mais material para formar sua cognição.

Em relação ao depoimento da parte, ressalte-se que é forma de provocar a confissão da parte adversa. A confissão, para se configurar, pressupóe admissão de fato desfavorável da parte confitente, mas favorável ao interesse da parte adversária. Tem por consequência, segundo Marinoni e Arenhart, a exoneração da prova do fato pela parte contrária e a efetivaçáo de prova da veracidade sobre o fato confessado ${ }^{29}$.

Há de se ponderar que, no caso de assédio moral praticado por um membro específico da família, a parte autora deve ter a prerrogativa de pedir o depoimento do assediador em

26 Conceitualmente, empregado doméstico é "aquele que presta serviços de forma contínua, subordinada, onerosa e pessoal e de finalidade não lucrativa à pessoa ou à família, no âmbito residencial destas, por mais de 2 (dois) dias por semana", nos termos do art. $1^{\circ}$ da Lei Complementar no 150/2015. A Lei 5.859/72 também indicava a pessoa ou família como empregadores domésticos.

27 JÚNIOR, Antonio Umberto de Souza. O novo direito do trabalho doméstico de acordo com a Lei Complementar n. 150/2015, p. 79.

28 Enunciado de Súmula no 337 do TST: Exceto quanto à reclamaçấo de empregado doméstico, ou contra micro ou pequeno empresário, o preposto deve ser necessariamente empregado do reclamado. Inteligência do art. 843, $\$ 1^{\circ}$, da CLT e do art. 54 da Lei Complementar no 123 , de 14 de dezembro de 2006.

29 Idem, p. 447. 
específico para fins de confissão provocada. Ou seja, deve poder direcionar o depoimento pessoal para um sujeito específico - o assediador - e por essa razão este deve figurar o polo passivo da ação.

Eis uma polêmica. A Justiça do Trabalho, na prática, não exige a indicação nem a presença de todos os componentes da família para quem o trabalhador ou trabalhadora doméstica prestaram serviços. Um membro apenas pode representar toda a família. E, paradoxalmente, entende-se que a sentença produz efeitos para todos eles. As consequências dessa forma - no nosso sentir - equivocada de compreender a legitimidade passiva na relaçáo de emprego doméstico pode criar óbices na execução da sentença.

O cuidado adicional que a parte autora e o próprio juiz devem ter na instrução processual, portanto, é reforçar a necessidade da presença do agressor na audiência de instrução, viabilizando-se a ampla defesa.

\section{c) OITIVA DE INFORMANTE}

Também destacamos que a oitiva de informante deve ser autorizada com maior maleabilidade nas hipóteses com a tratada neste trabalho. Note-se que a oitiva de informante não é vedada pelo ordenamento jurídico, pois nos termos do art. $447 \$ 3^{\circ}$, os amigos íntimos são suspeitos, e, assim, como os impedidos de depor na condição de testemunhas, podem ser ouvidos como informantes, como autoriza os parágrafos seguintes:

$$
\text { Art. } 447 \text { (...) }
$$

$\$ 4$ o-Sendo necessário, pode o juiz admitir o depoimento das testemunhas menores, impedidas ou suspeitas.

$\$ 5^{\circ}$-Os depoimentos referidos no $\$ 4^{\circ}$ - serão prestados independentemente de compromisso, e o juiz lhes atribuirá o valor que possam merecer.

A redação do Código de Processo Civil de 2015 é menos rigorosa que o texto anterior, que condicionava a oitiva à condição de estrita necessidade. Saliente-se, por fim, que o depoimento do informante submeter-se-á ao juízo de ponderação do julgador, que lhe atribuirá o peso que entender razoável.

\section{d) DISTRIBUIÇÁO DINÂMICA DO ONUS PROBANDI}

Em face do art. $6^{\circ}$ do CPC, há de se interpretar que todas as partes na lide têm o dever de colaboração na elucidaçáo dos fatos e formação do convencimento do juiz. Cuida-se de um princípio que deve permear todos os atos do processo e cuja inobservância deve ensejar litigância de má-fé.

Deveras, o fato constitutivo do direito referente aos danos extrapatrimoniais alegados pelo trabalhador deve ser provado por este, a teor do art. 373, I, do CPC. No caso, consideran- 
do as peculiaridades já aventadas, conclui-se que é dificultosa a prova, o que não justifica, no entanto, a inversão apriorística do ônus da prova, pois também é difícil a comprovação de suposto fato contrário.

Nesse estudo, ao se identificar as dificuldades de ordem processual no tocante à prova de assédio moral sofrido pelos trabalhadores domésticos não se quer perder de vista que também há abuso postulatório e acusaçôes levianas em face do empregador. Mas para combater eventuais demandas temerárias há mecanismos legais previstos no ordenamento jurídico, e não seria razoável que o abuso fosse considerado "regra" e com isso a sua repressão acabar comprometendo o próprio Acesso à Justiça.

Casuisticamente, o julgador deverá ponderar qual das partes tem maior aptidão para a prova e, assim, fixar os ônus equitativamente. Não há uma solução para todos os casos, mas há uma exortação de que o magistrado esteja atento e consciente, e em alguns casos seja mais proativo, para assim cumprir a nobre missão que lhe recai.

No entanto, nota-se que há muita resistência em se propiciar uma tutela efetiva de direitos aos trabalhadores domésticos, o que precisaria de muita boa vontade do juiz no uso dos seus poderes instrutórios. Acontece que o magistrado não é um ser impassível e deve se projetar, como provável empregador doméstico que é, na situação levada ao Judiciário e - de forma consciente ou não - empaticamente à posição do empregador, e se posicionar de modo a legitimar o que ele próprio (como empregador) não faz.

Ou seja, supóe-se que pode haver a leniência velada do magistrado em demandas dessa natureza, dificultando ainda mais a posição do empregado doméstico na relação jurídico - processual. Sendo assim, deve-se fomentar uma mudança de mentalidade para fortalecer a efetividade da Justiça nessas relaçóes, sobretudo no que diz respeito à temática dos danos de ordem extrapatrimonial, de tão dificultosa comprovação.

Enfim, o que se verifica é a inegável fragilidade do trabalhador doméstico em comprovar os abusos sofridos de ordem moral. E não se trata de uma mera contingência, também havendo, no nosso sentir, colaboração do Judiciário para que essa disparidade se perpetue, sobretudo pelas restriçóes de ordem processual impostas quando deveria haver maior maleabilidade instrutória e valorização do princípio da oralidade.

\section{CONSIDERAÇÓES FINAIS}

O presente estudo retrata uma disparidade, de ordem processual, relacionada às demandas judiciais de empregados domésticos, que remonta a outras desigualdades reveladoras de uma lamentável realidade histórica, refletida na legislação brasileira e que, por anos, reforçou uma mentalidade escravocrata e desprotegeu muito mais do que protegeu aquele nicho de trabalhadores. 
No presente trabalho buscamos apontar um aspecto de um fenômeno invisibilizado, que é o assédio moral nas relaçóes de emprego doméstico, fazendo um recorte de eventos judicializados, em que se verificou que mecanismos de proteçấo também devem ser lançados mão para que abusos de direito não sejam também silenciados pelo Judiciário.

Acreditamos, com isso, contribuir para a construção de uma visão crítica dos fenômenos jurídicos envolvendo a categoria dos trabalhadores domésticos, quiçá um passo para se ampliar a conscientização de direitos e a construção de uma sociedade mais democrática e inclusiva. As desesperanças fomentadas pela reforma trabalhista implementada em 2017, e pelas leis subsequentes também no sentido de precarizar as relaçóes de trabalho, marcando um Estado despreocupado com a justiça social, não devem esmorecer os ânimos para seguir a missão em defesa da classe trabalhadora, com suas vulnerabilidades ínsitas, afinal a luta pela Justiça é atemporal e ubíqua.

\section{REFERÊNCIAS}

BERNARDINO-COSTA, Joaze. Saberes Subalternos e Decolonialidade: os sindicatos das trabalhadoras domésticas no Brasil. Brasília: Editora Universidade de Brasília, 2015.

BRASIL. Decreto-lei n. ${ }^{0} 5.452$, de $1^{\circ}$ de maio de 1943. Aprova a Consolidaçáo das Leis do Trabalho. Disponível em: http://www.planalto.gov.br/ccivil_03/decreto-lei/del5452. htm. Acesso em: 20 out. 2019.

Constituiçáo da República Federativa do Brasil (1988). Disponível em: < http://www.planalto.gov.br/ccivil_03/constituicao/constituicao.htm>. Acesso em $28 \mathrm{de}$ outubro de 2019.

. Lei 13.105, de 16 de março de 2015. Aprova o Código de Processo Civil. Disponível em: <http://www.planalto.gov.br/ccivil_03/_ato2015-2018/2015/lei/113105.htm> Acesso em 28 de outubro de 2019.

BRITES, Jurema. Afeto e desigualdade: gênero, geração e classe entre empregadas domésticas e seus empregadores. Cadernos Pagu. On-line version ISSN 1809-4449, 2007.

CAPPELLETTI, Mauro. Acesso à Justiça. Trad. Ellen Gracie Northfleet. Porto Alegre: Fabris, 1988.

COSTA, Joana Simóes de Melo, BARBOSA, Ana Luiza Neves de Holanda e HIRATA, Guilherme. Efeitos da Ampliaçáo dos Direitos Trabalhistas sobre as condiçóes de trabalho das empregadas domésticas. Rio de Janeiro: Ipea, 2016.

DIDIER JR, Fredie Didier; BRAGA, Paula Sarno; OLIVEIRA, Rafael Alexandria de, Curso de Direito Processual Civil, 12a. Ed, Salvador: Ed. Juspodivm, Volume 2, 2016.

DELGADO, Maurício Godinho, DELGADO, Gabriela Neves. O novo manual do tra- 
balho doméstico - com os comentários aos artigos da LC n. 150/2015. 2a ed., São Paulo: LTR, 2016.

DELGADO, Maurício Godinho, DELGADO, Gabriela Neves. A reforma trabalhista no Brasil: com os comentários à Lei n. 13.467/2017. São Paulo: LTR, 2017.

HIRIGOYEN, Marie-France. Mal-estar no trabalho: redefinindo o assédio moral. Tradução Rejane Janowitzer, 3a ${ }^{\text {a }}$ Ed, Rio de Janeiro: Bertrand Brasil, 2006.

HIRIGOYEN, Marie-France. Assédio Moral: a violência perversa do cotidiano. 7a. Ed. - Rio de Janeiro: Bertrand Brasil, 2005

LEITE, Carlos Henrique Bezerra. Curso de Direito Processual do Trabalho, São Paulo: Saraiva, 2015.

LEITE, Carlos Henrique Bezerra, LEITE, Laís Durval e LEITE, Letícia Durval. A nova lei do trabalho doméstico: comentários à Lei Complementar n. 150/2015. São Paulo: Saraiva, 2015.

MARINONI, Luiz Guilherme, ARENHART, Sérgio Cruz. Prova. 2a ed., São Paulo: Editora Revista dos Tribunais, 2011.

PINHEIRO, Luana Simões, MEDEIROS, Marcelo. Desigualdades de gênero em tempo de trabalho pago e náo pago no Brasil. Rio de Janeiro: Ipea , 2013.

RODRIGUES, Américo Plá. Princípios de Direito do Trabalho. $3^{a}$ Ed., São Paulo: LTR, 2000. (Bernardino-Costa, 2015)

SCHIAVI, Mauro, Manual de Direito Processual do Trabalho, $10^{\text {a }}$ ed. - de acordo com o novo CPC - São Paulo: LTR, 2016.

SOUZA JÚNIOR, Antônio Umberto de. O novo direito do trabalho doméstico de acordo com a Lei Complementar n. 150/2015, São Paulo: Saraiva, 2015.

TST. RECURSO DE REVISTA: RR-1540/2005-046-12-00.5. Relator: Ministro Guilherme Augusto Caputo Bastos. DJ: 04/05/2009. 